\title{
Electric Transfer Function Model of Switched Reluctance Motors and the Model-Based Current Control Design
}

\author{
Hiroki IshikawaＭember (Gifu University, ishikawa@gifu-u.ac.jp) \\ Ryoko KomakiＳtudent Member（Gifu University,13128018@edu.gifu-u.ac.jp) \\ Haruo Naitoh Member (Gifu University, naitoh@gifu-u.ac.jp) \\ Akira Yamaba Non-member (JTEKT Corporation) \\ Hiroki Katoh Non-member (TOYOTA AUTO BODY CO., LTD.)
}

Keywords: SRMs, electric transfer characteristic, current response

Switched reluctance motors (SRMs) are robust, inexpensive, and easy to be manufactured owing to the absence of windings and permanent magnets in the rotors, which are simply made of iron and well suited for high-speed applications. Other advantages include high peak torque-to-inertia ratios, fault-tolerant operation, and so forth.

Despite the above advantages, however, the following disadvantages are well known. They are high ripple content in torque, audible noise generation, electromagnetic interference noise generation, and so on. From the viewpoint of current and speed control, the followings are substantial obstacles. Unlike dc motors, and vectorcontrolled synchronous and induction motors, the generated torque of SRMs is not proportional to the armature current, but roughly proportional to the square of the current. This relationship, inconveniently, is not consistent but varies depend on the operation points, which are determined with rotor speed and motor current. Moreover, the transfer characteristic from input voltage to the input current is not known well. These drawbacks have prevented the widespread use of SRMs.

This paper presents a current control design for SRMs. The electric transfer characteristic of the motors is studied first. Their transfer function is brought out to be represented by a pure resistive component. Its value, however, is not constant but varies depending on the motor current and rotor speed.

The mutual inductances between the phases in SRMs are very small. At any instant of time except during commutation, only one phase conducts while the other two phases are at off-state. The consideration indicates that the current waveform in one phase winding is almost immune to those of any other phases. Consequently, the average of the instantaneous current is not affected by the foregoing state. This means that the average current flows with its value corresponding to the applied voltage without any dynamics.

No dynamics in current response on the change in applied voltage means that the electric transfer function $\mathrm{G}_{\mathrm{ELEC}}(\mathrm{s})$ can be represented equivalently by a resistor. The resistance is not constant but varies with motor current and speed. The $\mathrm{G}_{\mathrm{ELEC}}(\mathrm{s})$ from the applied voltage $\mathrm{E}$ to the average current $\mathrm{I}$ is, therefore, represented by

$$
G_{E L E C}(s)=\frac{I}{E}=\frac{1}{R_{E Q}}
$$

where $\mathrm{R}_{\mathrm{EQ}}$ is an equivalent resistor and its value varies depending on the operating points.

In the design practice for the DCMs current controllers, the zero of PI compensator is set to cancel the pole of the electric transfer function of DCM of $1 /(\mathrm{Ls}+\mathrm{R})$. The resultant transfer function of the
PI controller and electrical dynamics of DCM in series is a pure integral component. The closed loop transfer function results in a first-order delay.

In order to follow this design, an I controller instead of a PI controller is sufficient for SRMs because the transfer function of SRMs is purely resistive and does not has any poles. Figure 1 shows the resultant current control loop for SRMs.

As previously mentioned, the equivalent resistor of SRMs is not constant. The integral gain $\mathrm{K}_{\mathrm{I}}$ has to be adjusted during operation according to change in the operating conditions or to the rotating speed and the average motor current. The values of the integral gain are tuned and tabulated for the motor speed and current. The table is, therefore, two dimensional.

In Fig. 2, experiments were carried out with the tabulated values of $\mathrm{K}_{\mathrm{I}}$. It is seen that the current exhibit almost the same response regardless of changes in the motor speed and current.

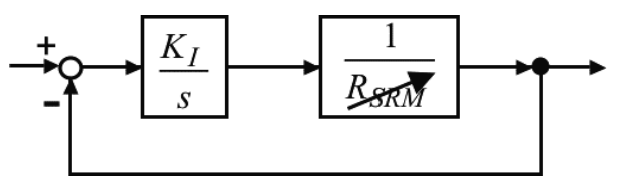

Fig. 1. Block diagram of electric current control for SRMs

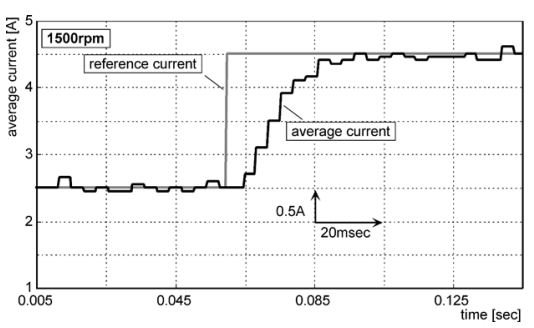

(a) Current step response at $1500 \mathrm{rpm}$

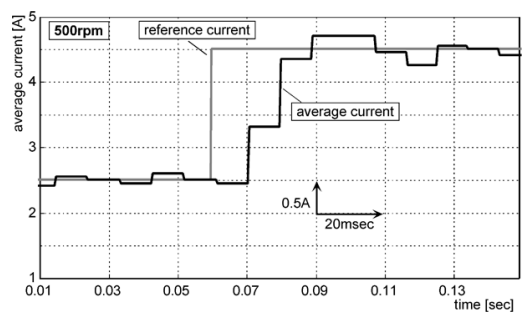

(b) Current step response at $500 \mathrm{rpm}$

Fig. 2. Current response experimental result with tabulated I-gain 


\title{
SRMの電気的伝達関数とそれに基づく電流制御系の設計法
}

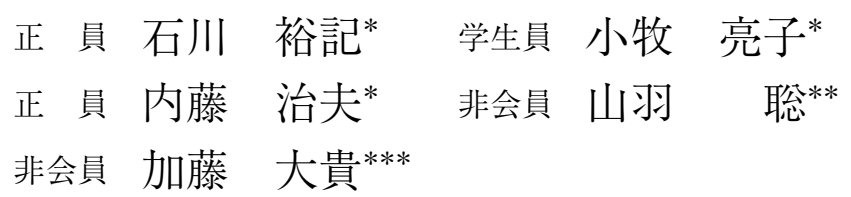

\author{
Electric Transfer Function Model of Switched Reluctance Motors \\ and the Model-Based Current Control Design
}

Hiroki Ishikawa*, Member, Ryoko Komaki*, Student Member, Haruo Naitoh*, Member,

Akira Yamaba**, Non-member, Hiroki Katoh***, Non-member

This paper presents a current control design for switched reluctance motors (SRMs). The electric transfer characteristic of the motors is studied first. Their transfer function is brought out to be represented by a pure resistive component, which is not constant but varies depending on the motor current and speed. The current control design for SRMs follows the classical design technique used for dc machines, where the zero of PI controller cancels the pole of Ls+R. Because the transfer function of SRMs does not have any poles, an I controller is suitable for them. The integral gain should be adjusted in order to compensate the non-linearity, that is, the variation in the equivalent resistor of the SRMs' transfer function. The values of the integral gain are tuned and tabulated for the motor speed and current. Simulation and experiment demonstrate that the current and speed of the SRMs presents good responses without dependence on the motor speed and current.

キーワード : SRM, 電気的伝達関数, 電流応答

Keywords: SRMs, electric transfer characteristic, current response

\section{1. まえがき}

スイッチトリラクタンスモータ (以下, SRM と略記) は, 以下に示す特長などから, 可変速駆動用モータとして有望 視されてきた。

回転子が鉄心だけで構成されるため

・低コスト

・回転子に巻線がないため, 回転子銅損がなく, 高効率

・遠心力に強く, 高速運転に適す

* 岐皁大学工学部人間情報システム工学科

厂 501-1193 岐阜市柳戸 1-1

Gifu University

1-1, Yanagido, Gifu 501-1193

** (株) ジェイテクトメカトロ制御技術部制御開発室

₹ 448-0803 愛知県刈谷市野田町北地蔵山 1-7

JTEKT CORPORATION Controller Development Sect. Mechatronics Control Design Dept.

1-7, Kita-jizouyama, Noda-cho, Kariya, Aichi 448-0803

*** トヨタ車体（株）第 2 生産技術部 第 1 ボデー計画室

₹ 448-8666 愛知県刈谷市一里山町金山 100 番地

TOYOTA AUTO BODY CO., LTD. Body Planning Dept. No.1

Production Engineering Div. No2

1-7, Kita-jizouyama, Noda-cho, Kariya, Aichi 448-8666
欠点としては，トルク脈動や騒音が大きいことが挙げられ る。これまで有限要素法などにより，これらを低減する構 造設計について研究が進められてきている(1)(2)。トルク平滑 化に関しては, 最適電流パターンに電流瞬時值を追従させ る方法などが報告されている(3)(4)。これらの, SRMのモー 夕単体としての盛んな研究に対比すると, SRM は可変速 モータでありながら可変速ドライブ制御系に組み込んだ研 究報告事例 ${ }^{(5)}$ (7) はあまり多くない。

可変速駆動用モー夕は当初, 直流電動機（厳密には分巻 直流電動機：以下，単に直流電動機と記す）が主流であっ た。近年では, 誘導電動機や永久磁石 $\mathrm{AC}$ サーボモータが 直流電動機を凌駕し, 可変速駆動用モー夕の主流となって いる。これらの電動機の電流制御系の設計では, 従来の直 流電動機と同じく, 補償要素に PI（比例積分制御）要素を 用いるのが一般的である。PI 要素の伝達関数の零点で電機 子回路の伝達関数の極を打ち消し (極零相殺), 電流制御 フィードバック系全体として一次遅れ系とし, その時定数 （または整定時間）が設計仕様を充たすよう比例および積分 ゲインを決定する。この設計法は簡便で極めて見通しのよ い設計法である。

本論文では, SRM の電流制御系の設計にも上記の方法を 


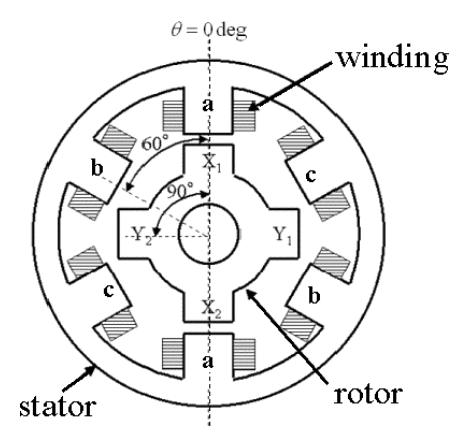

Fig. 1. Cross sectional view of switched reluctance motor.

適用できるようにする。まず，SRM の電気的応答特性，つ まり印加電圧に対する電流の応答特性を考察する。その結 果, SRM の電流応答には過渡現象がないこと, その伝達関 数が可変值の抵抗要素で表されることを明らかにする。こ の結果に基づき, SRMの電流制御系の設計法として, 直流 電動機と同じ方法，すなわち電流フィードバック系全体と して一次遅れ系を構成する方法を示す。そこでは制御論理 として積分制御のみを用いればよく, 調整パラメー夕は積 分ゲインのみである。

SRM は応答特性の動作点依存性が極めて強いモータであ る。伝達関数においては, その可変抵抗要素がこのことを 表している。制御ゲイン（積分ゲイン）を一定值とする制 御法では，この依存性を克服するのが困難である。この問 題を解決するために，本文では，積分ゲインを，電流制御 系のステップ応答の実験により事前にテーブル化する。稼 働中に電流制御周期ごとにその時の動作点に応じた積分ゲ インをテーブル検索により求める。

制御ゲインのテーブル化による方法は，Rahman 等によ る方法が報告されている(5)。そこでは，制御論理として PI が採用されている。このためテーブル化に際しては，積分 ゲインだけでなく，本質的に不必要な比例ゲインも決定し なければならない。この方法では電流応答の設計指針も不 明確である。これらのことがテーブル化の作業を著しく煩 雑で時間がかかるものとしている。本論文の方法によれば 不必要な比例ゲインを決定する必要が無く, テーブル化の 作業が簡潔である。

最後に，シミュレーションと実験により，本制御法の有 効性を検証する。

\section{2. 供試 SRM と駆動回路}

Fig. 1 は供試 SRM の断面図，Table 1 はその仕様である。 固定子 6 極，回転子 4 極の $6 / 4$ 構造である。回転子位置 $\theta$ は, $\mathrm{a}$ 相の固定子突極と回転子突極が対向した回転子位置 を $\theta=0$ [deg] とし，時計回りを正とする。

Fig. 2 は, SRM の駆動回路である。6 個のトランジスタと 6 個のダイオードで構成されている。四角で囲んだ部分は, $\mathrm{SRM}$ の等価回路である。 $\mathrm{R}_{\mathrm{a}}, \mathrm{R}_{\mathrm{b}}, \mathrm{R}_{\mathrm{c}}$ は各相の巻線抵抗， $\mathrm{L}_{\mathrm{a}}, \mathrm{L}_{\mathrm{b}}, \mathrm{L}_{\mathrm{c}}$ は各相の等価インダクタンス, $\omega_{\mathrm{m}} \mathrm{K}_{\mathrm{Ea}}, \omega_{\mathrm{m}} \mathrm{K}_{\mathrm{Eb}}$,
Table 1. SRM parameters.

\begin{tabular}{|l|c|}
\hline rated power & $1.5 \mathrm{~kW}$ \\
\hline rated rotor speed & $1500 \mathrm{rpm}$ \\
\hline rated voltage & $200 \mathrm{~V}$ \\
\hline rated current & $4.3 \mathrm{~A}$ \\
\hline rated torque & $9.55 \mathrm{Nm}$ \\
\hline stator phase / pole number & $3 / 6$ \\
\hline rotor pole number & 4 \\
\hline
\end{tabular}

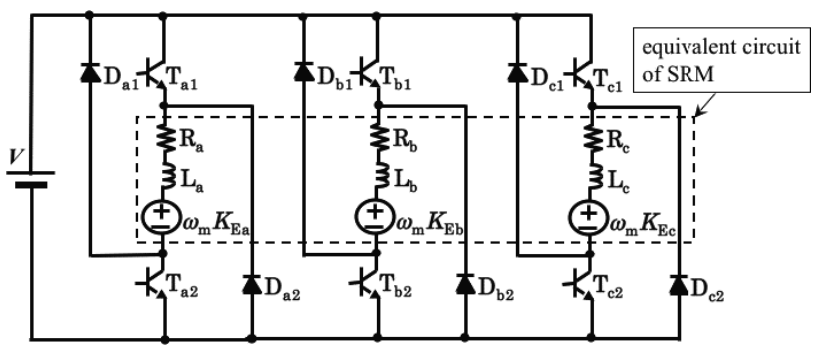

Fig. 2. SRM drive circuit.

$\omega_{\mathrm{m}} \mathrm{K}_{\mathrm{Ec}}$ は各相の速度起電力である。

回転子位置に応じて, スイッチ $\mathrm{T}_{\mathrm{a} 1}$ と $\mathrm{T}_{\mathrm{a} 2}, \mathrm{~T}_{\mathrm{b} 1}$ と $\mathrm{T}_{\mathrm{b} 2}$, $\mathrm{T}_{\mathrm{c} 1}$ と $\mathrm{T}_{\mathrm{c} 2}$ を順次適宜オン・オフし, 固定子突極の励磁を $\mathrm{a}$ 相 $\rightarrow \mathrm{b}$ 相 $\rightarrow \mathrm{c}$ 相と切り替えて回転子を回転させる。

本文では, 励磁角を $-35^{\circ}$, 消磁角 $-5^{\circ}$ に設定した。SRM の瞬時電流波形はこれらの角度に依存して大きく変化する が，後述するように，本論文の電流制御系設計では電流の 区間平均值を用いるので，本文の電流制御系設計はこの設 定值には依存しない。卷線に印加される電圧の大きさを変 えるために, Fig. 2 の上側のスイッチ $\mathrm{T}_{\mathrm{a} 1}, \mathrm{~T}_{\mathrm{b} 2}, \mathrm{~T}_{\mathrm{c} 2}$ を三角 波比較 PWMにより, 適宜チョッパ動作をさせる。PWM のキャリア周波数は $10 \mathrm{kHz}$, 電源電圧 $\mathrm{V}$ （電源が整流回路 の場合は直流中間電圧）は $120 \mathrm{~V}$ とした。

\section{SRM の電気的応答特性と伝達関数}

本章では, SRM の電気的応答特性を考察し，これに基づ き伝達関数モデルを導出する。伝達関数は電流のフィード バック制御の設計用の伝達関数である。

$\mathrm{SRM}$ のように瞬時電流波形の脈動が大きい制御対象に 電流制御を行う場合は，瞬時電流值を用いることはできな い。脈動周期での電流平均值，つまり区間平均を用いて電 流制御を施す。SRM での脈動周期は電気角 $120^{\circ}$ である。 電気角であるから，その時間幅，つまり電流制御周期は回 転速度に依存する可変周期である。本研究ではこれに合わ せて, 電流検出も電気角 $120^{\circ}$ 周期, 速度制御周期は電流制 御周期の 6 倍としている。

ちなみにサイリスタレオナードではサイリスタ整流器の 出力電流つまり直流電動機の入力電流に $60^{\circ}$ 周期の大きな 脈動が重畳するので，この周期で SRM と同様に区間平均 值で電流を制御する。ベクトル制御を施した誘導電動機や 同期電動機などでは, 三相一二相変換した後の電流成分が理 論的には純直流量で脈動がないので，この区間平均の概念 がない。 


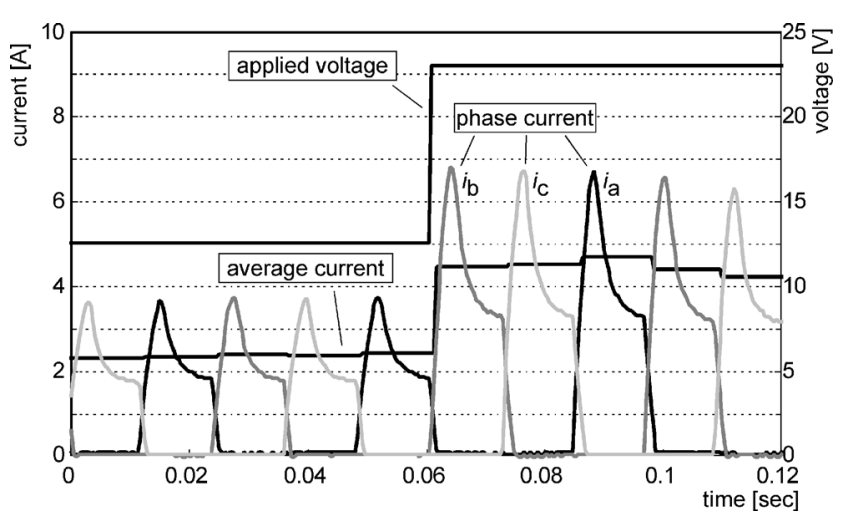

Fig. 3. Current responses for step change in voltage.

従って, この伝達関数は各相の電流の通流期間（電気角 $120^{\circ}$ ）ごとの平均值の応答を規定するものである。

誘導電動機や同期電動機などでは, 電流は 3 相の巻線に, 大きさの差こそあれ，常時通流する。各相の電流は相互イ ンダクタンスを介して互いに影響を及ぼしあう。これに対 して SRM は通電している相以外，基本的には電流を流さ ない。実際には励磁相の切り替えの際の重なり期間に消磁 相と励磁相の電流が同時に流れるだけである。SRMでは 相間の相互インダクタンスが極めて小さい( ${ }^{(8)(9)}$ ので, 重な り期間に同時通流する電流の相互作用の影響も僅少である。 よって, 一つの卷線に電圧が印加されると, 瞬時電流はほ ぼその相の回路条件だけで定まる波形で通流する。瞬時電 流を通流期間ごとに平均した平均電流（以降，単に平均電 流と記す）も同じで，電圧が変化すると平均電流も直ちに 変化する。

このことを検証するために，SRMに方形波電圧を印加 し, 瞬時電流波形㧍よび平均電流を観測した。Fig. 3 は, そ

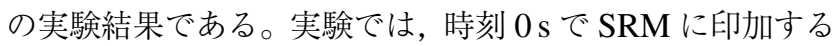
電圧を $12.5 \mathrm{~V}$ から $23 \mathrm{~V}$ ヘステップ状に変化させた。平均 電流は相電流から算出した。

実験結果から, ステップ状に増加した印加電圧に対し, 瞬 時電流波形は徐々に変化するのではなく, 電圧増加直後に 瞬時に変化し，その後その波形をほぼ維持していることが 分かる。Fig. 3では，ステップ変化した後の瞬時電流波形が 僅かながら徐々に小さくなっている。これは電流が増加し たことでトルクが増え, SRM の速度が漸増し, 逆起電力が 増大したためである。この現象は電気的応答ではなく, 機 械的応答によるものである。

平均電流もステップ状に変化している。このことは電圧 に対する平均電流の応答には過渡現象がないことを示唆し ている。

以上の考察を，自動制御理論的見地から検討する。直流 電動機などのように抵抗 R とインダクタンス L で構成され る電機子回路は一次遅れ系である。サンプリング期間ごと の平均電流の応答を記述する一次遅れ離散值系の差分方程 式は, $k$ 回目のサンプリング時に得られる状態変数を電流 $I(k)$ ，入力を電圧 $V(k)$ として，以下で与えられる ${ }^{(10)} 。$

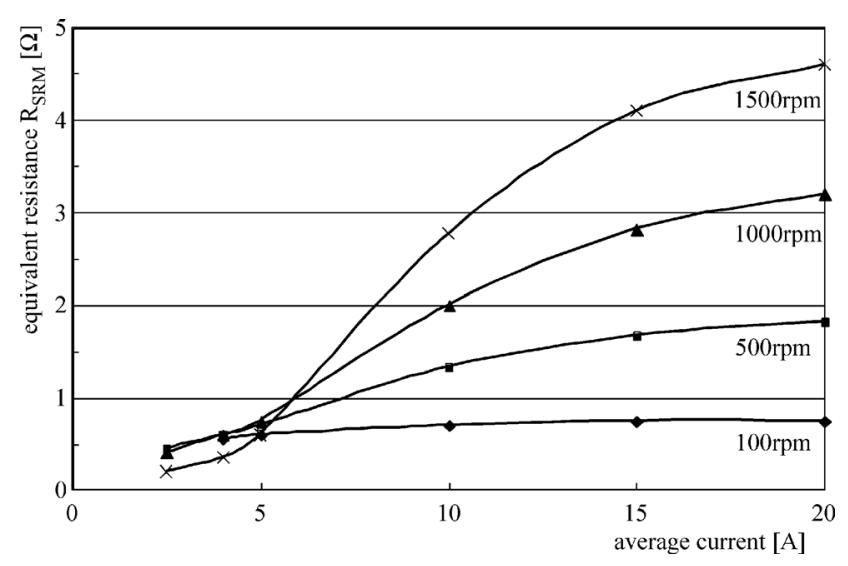

Fig. 4. Average electric current vs. equivalent resistance.

$$
\begin{aligned}
& I(k+1)=p I(k)+q V(k) \cdots \ldots . \\
& p=e^{-\Delta T / \tau} q=(1-p) / R \tau=L / R
\end{aligned}
$$

ここで $\Delta \mathrm{T}$ はサンプリング周期， $\tau$ は時定数である。ここ で着目すべき点は $p I(k)$ の項である。これは第 $\mathrm{k}$ 回の状態 変数 $I(k)$ が次回の状態変数 $I(k+1)$ に伝搬していることを 意味する。これが過渡現象として現れるのである(11)。

SRMでは先に考察したように, 現在通流している相の瞬 時電流ひいては平均電流は, 次に通流する相の瞬時電流ひ いては平均電流に殆ど影響を与えない。つまりSRM の伝 達関数の状態変数である平均電流は, あい連続するサンプ リング期間を越えて伝搬されることは殆ど無い。したがっ て過渡現象も無視できる。このことは一次遅れ系にて時定 数 $\tau$ が無限小に近い場合に相当する。この時，(2) 式から

$$
p \cong 0 q \cong 1 / R
$$

でここれらと(1)式から

$$
I(k+1) \cong q V(k) \cong \frac{V(k)}{R} .
$$

となり, 印加電圧から平均電流までの伝達関数は抵抗要素 で表現できるのである。

以上の考察から, $\mathrm{SRM}$ の伝達関数を $\mathrm{G}_{S R M}(s)$ とすると,

$$
G_{S R M}(S)=\frac{1}{R_{S R M}}
$$

と表すことができる。ここで $\mathrm{R}_{S R M}$ は $\mathrm{SRM}$ の等価抵抗で ある。

次に $\mathrm{R}_{S R M}$ について考察する。 $\mathrm{R}_{S R M}$ は, 印加電圧と逆 起電力の差を巻線平均電流で割ることで算出できる。Fig. 4 は回転数をパラメータとして, SRM の等価抵抗を求めたシ ミュレーション結果である。Fig. 4 から $\mathrm{R}_{S R M}$ は, 回転数 や平均電流に応じて変化する可変抵抗 $\left(\mathrm{R}_{S R M}\right)$ であること がわかる。

\section{SRM の電気的応答特性と伝達関数}

前章の考察を基に, SRM の電流制御系を設計する。本論 


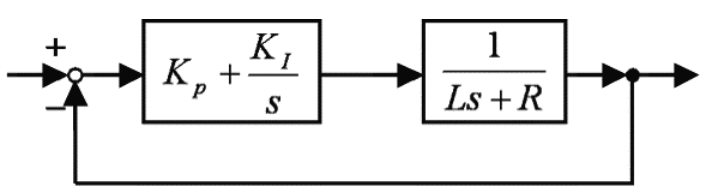

Fig. 5. Block diagram of current control of DCM.

文では直流電動機と同等の制御方式をめざす。

まず直流電動機の一般的な電流制御系について述べる。 この設計法を踏襲して，SRM の電流制御系を設計する。

$\langle\mathbf{4} \cdot \mathbf{1}\rangle$ 直流電動機の電流制御系設計 直流電動機の PI 制御器を適用する代表的な電流制御系の設計法を以下に 示す。対象となる系のブロック図を Fig. 5 に示す。

直流電動機の電気的伝達関数を $\mathrm{G}_{D C M}(s)$, 電流制御系 PI 制御器の伝達関数を $\mathrm{G}_{P I}(s)$ とすると, それぞれ下式で表す ことができる。

$$
\begin{aligned}
& G_{D C M}(S)=\frac{1}{L s+R} \cdots \ldots \ldots \ldots \ldots \ldots \\
& G_{P I}(S)=K_{P}+\frac{K_{I}}{s}=K_{I}\left(\frac{1+T_{P I} s}{s}\right)
\end{aligned}
$$

ただし， $\mathrm{T}_{P I}=\mathrm{K}_{P} / \mathrm{K}_{I}$ である。

(6)，(7) 式より，直流電動機の電流制御系の開ループ伝 達関数 $\mathrm{G}_{O P}(S)$ は，(8) 式で表すことができる。

$$
\begin{aligned}
G_{O P}(s) & =G_{P I}(s) G_{D C M}(s) \\
& =K_{I}\left(\frac{1+T_{P I} s}{s}\right)\left(\frac{1}{L s+R}\right) .
\end{aligned}
$$

ここで, $\mathrm{G}_{P I}(s)$ の零点と $\mathrm{G}_{D C M}(s)$ の極とで極零相殺を行 う。これには,

$$
T_{P I}=\frac{K_{P}}{K_{I}}=\frac{L}{R}
$$

と設定すれば，(4) 式右辺の $s$ の分子多項式と分母多項式が 約分でき，極零相殺できる。

その結果, $\mathrm{G}_{O P}(s)$ は積分要素

$$
G_{O P}(s)=\frac{1}{R} \frac{K_{I}}{s}
$$

で表される。この結果, Fig. 5 の電流制御系は, (10) 式の要 素を前向き路に持つ単一フィードバックループとなり，伝 達関数 $\mathrm{G}_{I D C M}(s)$ が $(11)$ 式の一次遅れ系を構成する。

$$
G_{I D C M}(s)=\frac{1}{1+\frac{R}{K_{I}} s} .
$$

上式の $R / K_{I}$ が時定数に対応するから, 電流制御系の設計 仕様により $K_{I}$ が決定でき，ひいては (9) 式から $K_{P}$ が定め られる。

$\langle\mathbf{4} \cdot \mathbf{2}\rangle \mathbf{S R M}$ の電流制御系伝達関数 次に SRM の電 流制御系について考える。前章で述べたように, SRMの電 気的伝達関数は, 等価的に(5) 式の可変抵抗要素で表すこ とができる。その電気的伝達関数には極が存在しないので, 制御器に零点は不要である。したがって SRM の電流制御

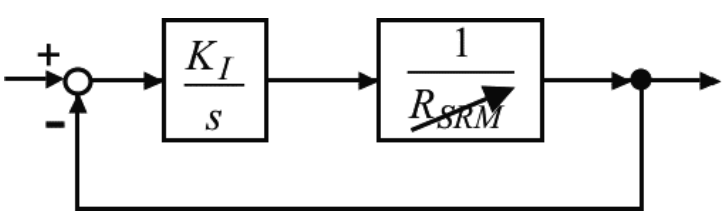

Fig. 6. Block diagram of electric current control.

器はPI 制御器として零点を持ち込む必要は全くなく, 積分 制御のみで十分である。なお，定常偏差を生じさせないこ と, 抢よび逆起電力に対応する電圧成分を保持ため, 積分 要素が不可欠であることは言を待たない。以上をまとめる と, $\mathrm{SRM} の$ 電流制御系開ループ伝達関数 $\mathrm{G}_{O P S R M}(s)$ は, I 制御器のゲインを $\mathrm{K}_{\mathrm{I}}$ として，(12) 式で表すことができる。

$$
G_{O P S R M}(s)=\frac{1}{R_{S R M}} \frac{K_{I}}{s}
$$

電流制御ループはこの伝達関数が前向き路に存在する単 一フィードバックループで, そのブロック図は Fig. 6 であ る。これより, $\mathrm{SRM}$ の電流制御系伝達関数 $\mathrm{G}_{I S R M}(s)$ は,

$$
G_{I S R M}(s)=\frac{1}{1+\frac{R_{S R M}}{K_{I}} s}
$$

である。これは, 先に導いた直流電動機の電流制御系伝達 関数 $\mathrm{G}_{I D C M}(s)$ と同形である。ただし前章で指摘したよう に，抵抗成分が動作点での回転数と平均電流に依存して変 化する点が異なる。したがって一定值の積分ゲインでは動 作点によって応答特性が変化してしまう。この問題を解決 するためには何らかの方法で積分ゲインを動作点に応じて 可変とする必要がある。

$\langle\mathbf{4} \cdot \mathbf{3}\rangle$ 定值積分ゲインの不適切性の検証 まずシミュ レーションにより，積分ゲインを一定值とした場合の応答 を確認しておく。Fig.7(a) に回転数 $1500 \mathrm{rpm}$ 近傍で良好な 応答が得られるように積分ゲインを調整・設定した場合の 電流のステップ応答シミュレーション結果を示す。電流指 令值は $3 \mathrm{~A}$ から $3.5 \mathrm{~A}$ ヘステップ状に変化させた。平均電 流は指令值に一次遅れで追従していることが分かる。

Fig. 7(b) では，積分ゲインを同図 (a) の回転数 $1500 \mathrm{rpm}$ 近傍での設定值のままとして, 回転数を $500 \mathrm{rpm}$ とした時 の電流のステップ応答シミュレーション結果である。電流 指令值のステップ変化は同図 (a) と同一である。この条件 ではステップ変化を加える以前から電流は大きく振動する。 つまり安定な定常動作点すら維持できない。以上の結果よ り, 同一の積分ゲインでは回転数の変化に伴うSRM の電 気的伝達関数の变化に対応できないことが分かる。

以上のシミュレーションでは, 積分ゲインの速度依存性 だけを検証したが, 電流依存性も同様である。実際に SRM を駆動する際は, 速度と電流を検索項とする二次元テーブ ルが必要である。

\section{5. 電流制御系の二次元テーブルと実験結果}

$\langle\mathbf{5} \cdot \mathbf{1}\rangle$ 二次元テーブル 二次元テーブルは Table 1 の 


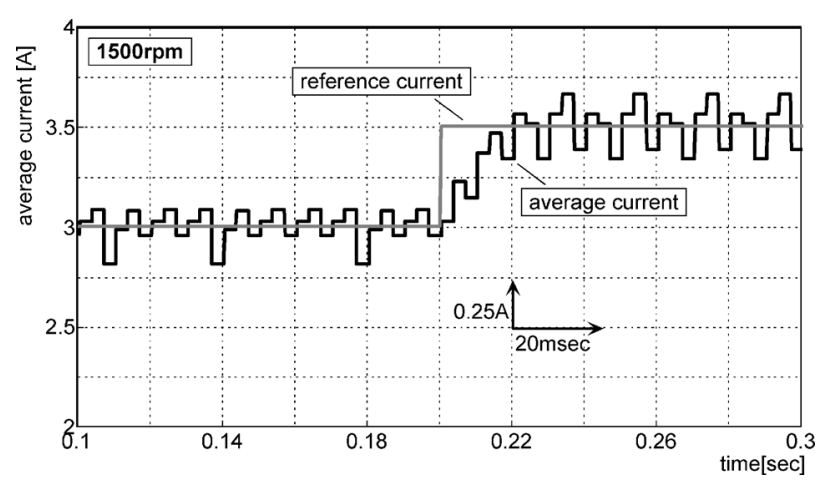

(a) Current step response at $1500 \mathrm{rpm}$

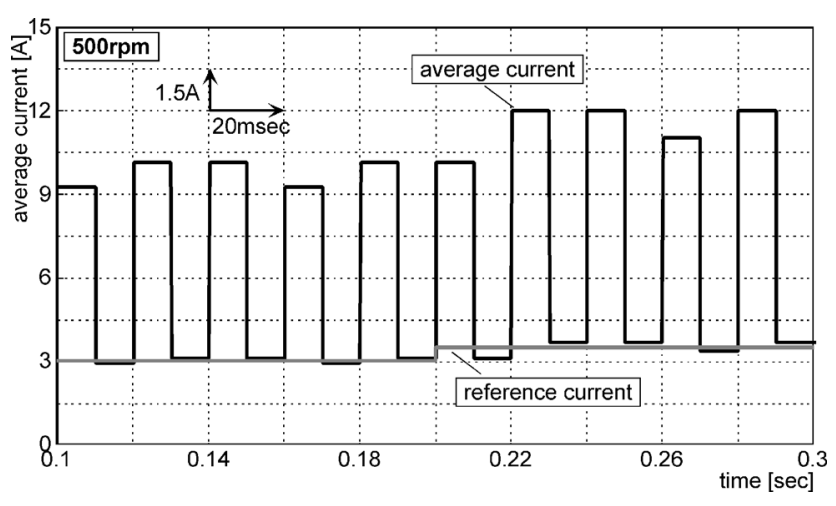

(b) Current step response at $500 \mathrm{rpm}$

Fig. 7. Current response simulation result with a constant I-gain.

定格の供試 SRM 用に，実験により求めた。速度に関して は，定格速度 $1500 \mathrm{rpm}$ までを $100 \mathrm{rpm}$ 刻みとした。電流 に関しては，短時間定格の過負荷耐量として電流定格の約 1.5 倍の $7 \mathrm{~A}$ までを $0.5 \mathrm{~A}$ 刻みとした。以上の刻み幅で定 まる各動作点にて電流のステップ応答を実測し，応答が仕 様を満たす積分ゲインの值を探索した。電流応答仕様は, その整定時間（整定值の 95\%に到達する時間）で規定し， $20 \mathrm{msec}$ とした。以上で得られた二次元テーブルを Fig. 8 に示す。刻み点間の動作点に対しては，隣接する刻み点の 積分ゲイン值間で線形内挿により当該動作点での積分ゲイ ン值を算出する。

$\langle\mathbf{5} \cdot \mathbf{2}\rangle$ 電流応答の実験結果 〈4·3 節のシミュレー ションで示したように，積分ゲインをある回転数レベルに て調整した一定值とした場合は, 回転数レベルを変えると 電流は激しく振動する。電流レベルに関しても同様である。 このため, 本節での実験では, 定值積分ゲインによる制御 の実験が成立しないので，テーブルを適用した実験結果だ けを示す。

$\langle 5 \cdot 1 〉$ 節で求めた積分ゲインの二次元テーブルを用いた 平均電流のステップ応答の実験結果を Fig. 9 に示す。同図 (a) は $1500 \mathrm{rpm}$ ，(b) では $500 \mathrm{rpm} に て ，$ 平均電流指令值を $2.5 \mathrm{~A}$ から $4.5 \mathrm{~A}$ に変化させた。これらの実験結果から, 速 度および電流レベルが大幅に変化しても, 整定時間 $20 \mathrm{msec}$ の電流応答仕様を充たす良好な一次遅れ応答が得られてい ることが検証できた。

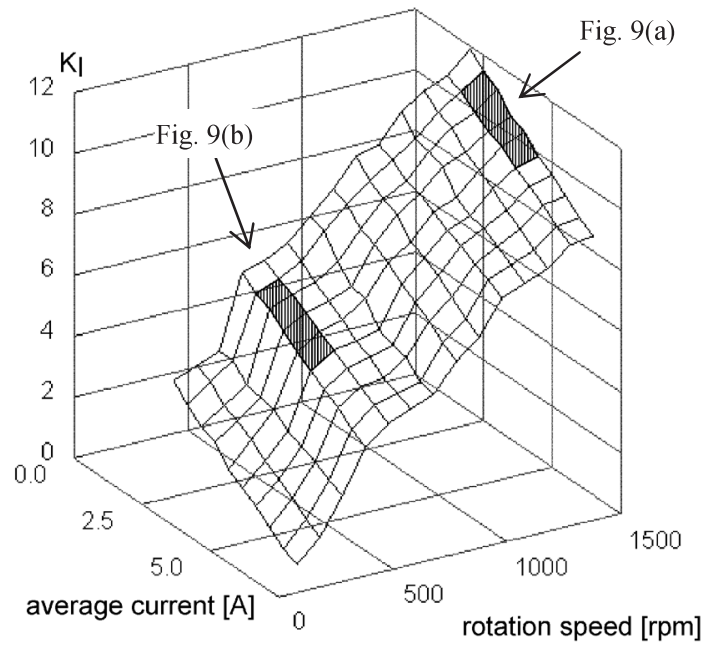

Fig. 8. Integral gain $\mathrm{K}_{\mathrm{I}}$ vs. speed and motor current.

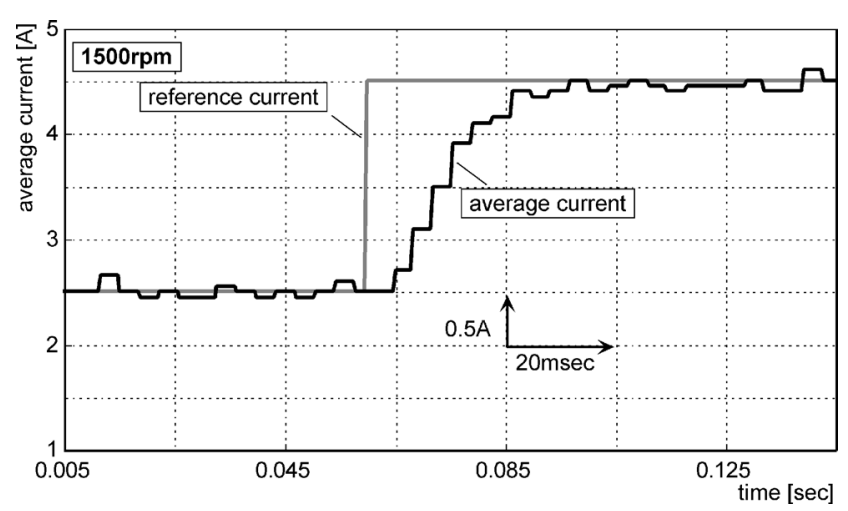

(a) Current step response at $1500 \mathrm{rpm}$

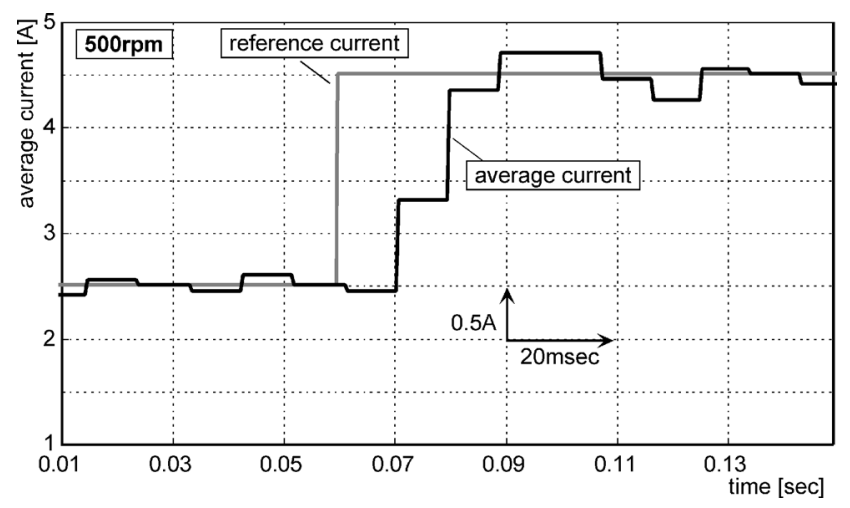

(b) Current step response at $500 \mathrm{rpm}$

Fig. 9. Current response experimental result with tabulated I-gain.

Fig. 8 の二次元テーブルには, Fig.9(a) および (b) の実験 での積分ゲインの值域をハッチングにて付記した。

\section{6. 速度応答の実験結果}

本章では，電流制御系をマイナーループにもつSRMの 速度制御系を構成して行った速度応答の実験結果を示す。 電流制御系では前章の二次元テーブルにより積分ゲインを オンラインで補正している。〈5·2〉節で指摘したのと同一 の理由により，定值積分ゲイン制御による実験は行ってい 


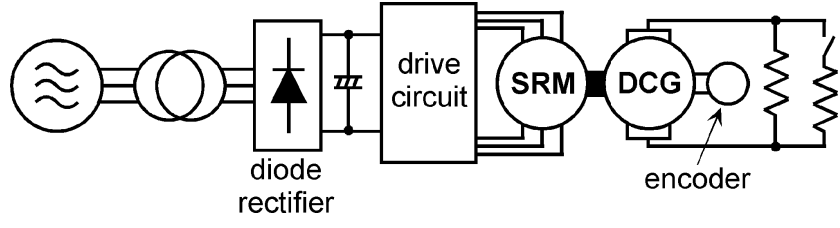

Fig. 10. Experiment setup.

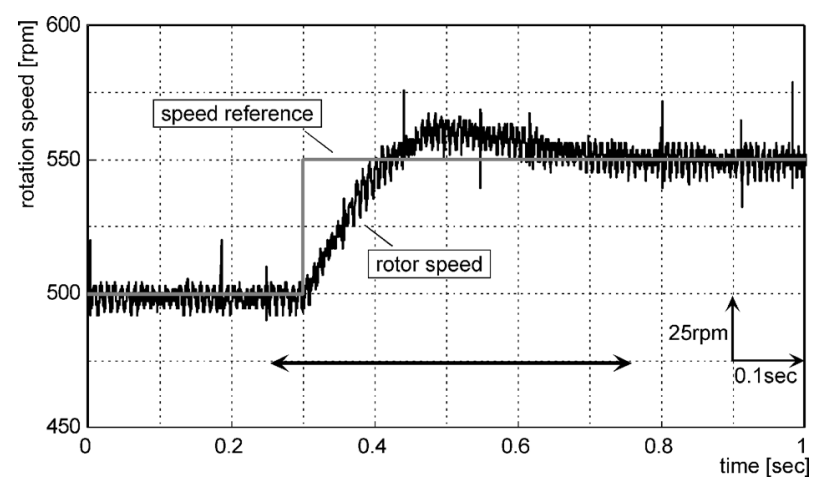

(a) Speed response

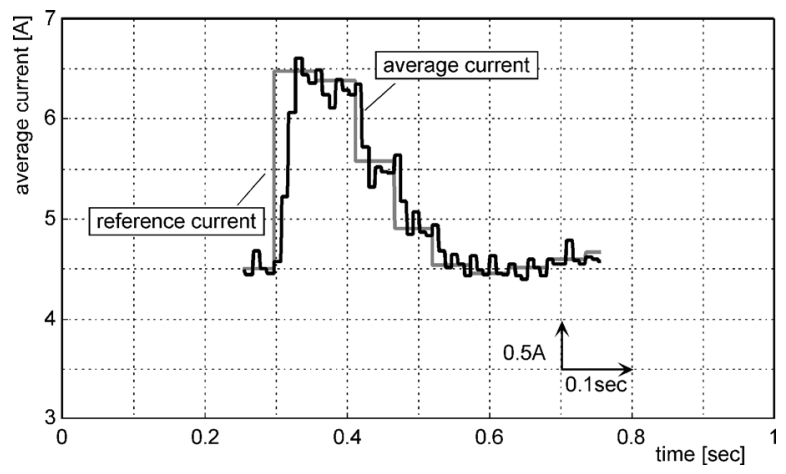

(b) Current response.

Fig. 11. Experiment result of speed response $(500 \rightarrow$ $550 \mathrm{rpm})$.

ない。速度制御系の制御論理はPIである。速度応答の仕様 は，速度指令のステップ変化に対し，電流応答の整定時間 の約 5 倍の時間（本論文では $100 \mathrm{msec}$ ）で約 20\%程度の非 振動的オーバーシュートを示し, 約 10 倍で整定することと した。これは速度制御論理としてPI のみを用いた場合の， 産業用電動機の典型的仕様例の一つである。

Fig. 10 に速度応答の実験装置の構成を示す。SRM には 直流発電機（以下 DCG と略記）を連結している。負荷応 答の実験では，DCGに接続した負荷抵抗を切り換えること で，負荷トルクをステップ状に変化させた。

Fig. 11(a) に，指令回転数を $500 \mathrm{rpm}$ から $550 \mathrm{rpm}$ にし たときの回転数の応答波形, Fig. 12(a) に, $1000 \mathrm{rpm}$ から $1050 \mathrm{rpm}$ にしたときの回転数の応答波形を示す。両応答と も制御仕様に適合した応答を示していることが確認できた。 両図の (b) は，それぞれの場合の電流応答の波形である。測 定装置のメモリ容量の制約から，電流波形はそれぞれ (a) 中 に双方向矢印で示した時間幅で観測した。両応答とも，速 度指令入力直後の鋭い電流指令の立ち上がりによく追従し ている。

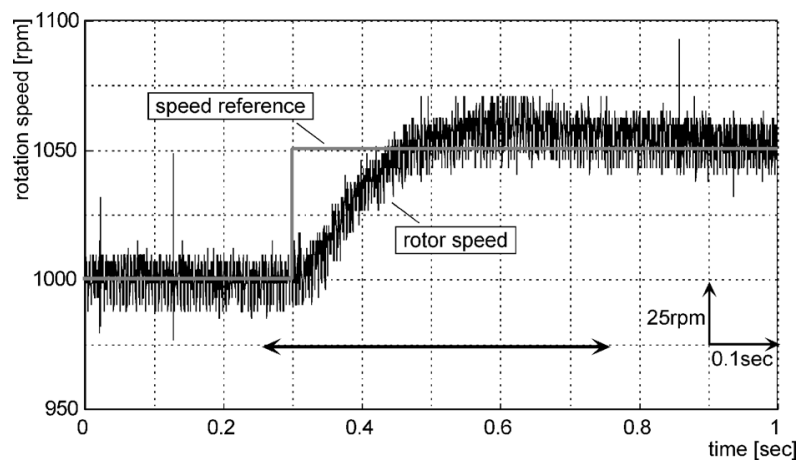

(a) Speed response.

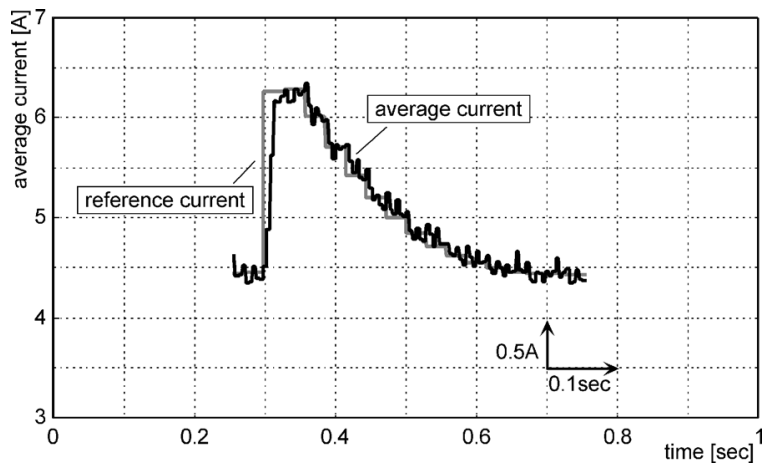

(b) Current response.

Fig. 12. Experiment result of speed response (1000 $\rightarrow$ $1050 \mathrm{rpm})$.

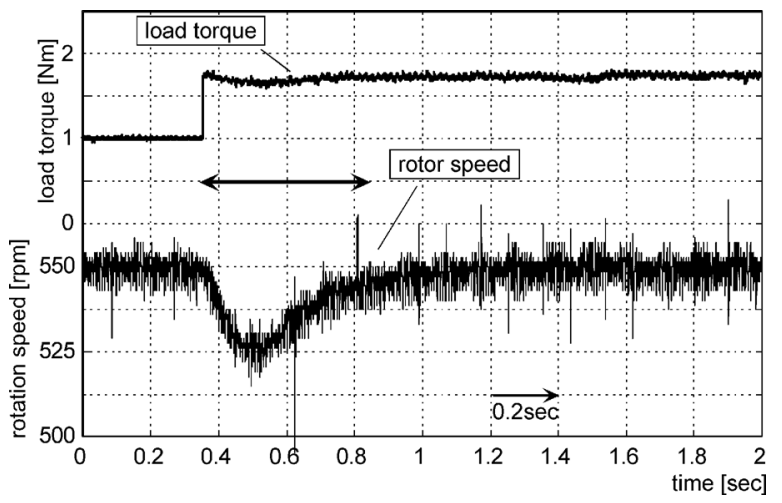

(a) Speed response.

(recovery time $400 \mathrm{~ms}$, speed drop $25 \mathrm{rpm}$ )

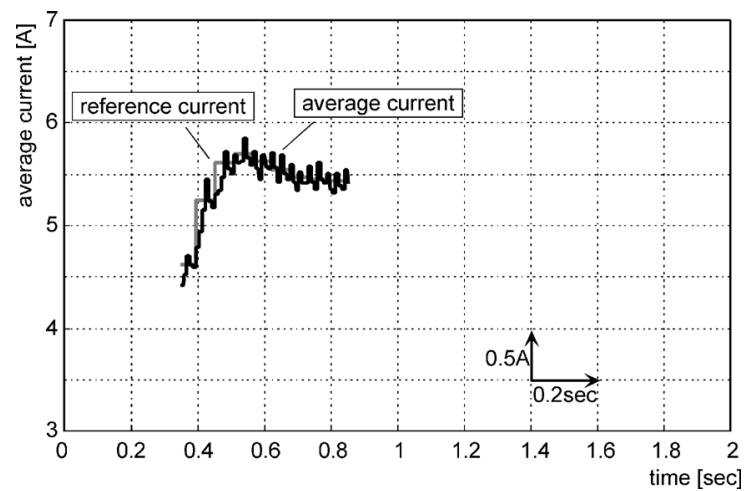

(b) Current response

Fig. 13. Experiment result of load response. 
Fig. 13(a)に, 回転数 $550 \mathrm{rpm}$ にて, 負荷トルクを $1.0 \mathrm{Nm}$ から $1.7 \mathrm{Nm}$ に変化させたときの負荷トルクの波形と回転 数の波形を示す。負荷トルクの变動に対して, 回転数は, 復 帰時間約 $400 \mathrm{~ms}$ で, 元の回転数に復帰している。(b) は, この間の電流応答波形である。ここでも, (a) 中の双方向矢 印で示した時間幅で観測した。

\section{7. むすび}

本論文は SRM の電気的応答特性について考察し, その 伝達関数が, 可変抵抗要素として表せることを明らかにし た。この結果に基づき直流電動機と同じ電流制御系，すな わち電流フィードバック系全体として一次遅れ系を構成す るには, PI 制御ではなく, 単独の積分制御が適しているこ とを示した。SRMの回転速度と電流で定まる動作点への, SRM の電流応答の依存性に対処するため, 供試 SRM につ いて，その動作領域での各動作点にて実験により最適な積 分ゲインを決定しテーブル化した。この際，電流応答を一 次遅れとするという明確な設計指針があり，かつ決定す心゙ き值が積分ゲイン一つだけであるので，テーブル化の作業 は単純で比較的に短時間で済ませられる。シミュレーショ ンおよび実験により，上記設計法で良好な電流・速度応答 が得られることを検証した。

SRM は騒音やトルク脈動が大きく，かつ制御しづらい 電動機である。このため, 実用に供する際は, 高速回転に 適している，低慣性モーメントのものが製作しやすい，構 造が堅牢で動作環境の悪い用途にも使える，などの SRM の特長を活かせる用途に限定して用いる，換言すれば，特 定用途指向性モータとして実用する方がよいと指摘されて いた ${ }^{(12)}$ 。卓見である。他方，希土類ではあるが比較的安価 であった磁石材料のネオジウムの価格が高騰しつつある現 在, ネオジウムが不可欠な永久磁石 AC サーボモータに代 替可能な電動機の一つとして SRM を再評価するのも選択 肢の一つであろう。そのためには上記の用途上の限界を克 服し, SRM の用途に汎用性を獲得するための技術の研究・ 開発が必須である。本論文はこの技術研究・開発の方向に 沿うものである。

(平成 19 年 11 月 28 日受付, 平成 20 年 4 月 4 日再受付)

\section{文献}

(1) M. Kaneda, M. Sanada, S. Morimoto, Y. Takeda, and H. Yamai: "Torque and Radial Forces of Switched Reluctance Motor", The Transactions of IEEJ, Vol.120-D, No.1, p.67-72 (2000-1) (in Japanese) 兼田昌子・真田雅之·森本茂雄・武田洋次・山井広之 :「スイッチトリ ラクタンスモータとラジアル力」, 電学論 D, 120, 1, pp.67-72 (2000-1)

(2) T. Sawada, Y. Yamaguchi, and TJE Miller: "Analysis of an Optimum Number of the Multi-Tooth per Pole SRM", IPEC-2000, pp.637-642 (2000)

(3) H. Ishikawa, D. Wang, and H. Naitoh: "A New Switched Reluctance Motor Drive Circuit for Torque Ripple Reduction", IEEE Proceedings of the PCC-Osaka 2002, Vol.2, pp.683-688 (2002)

(4) H. Ishikawa, Y. Kamada, and H. Naitoh: "Instantaneous Current control for Flat Torque of Switched Reluctance Motors", The Transactions of IEEJ, Vol.125-D, No.12, p.1113-1121 (2005-12) (in Japanese)

石川裕記・鎌田義信・内藤治夫：「スイッチトリラクタンスモータ
の瞬時トルクを一定にする電流波形とその波形成形制御法」, 電学論 D, 125, 12, pp.1113-1121 (2005-12)

(5) K.M. Rahman and S.E. Shultz: "High-Performance Fully Digital Switched Reluctance Motors Controller for Vehicle Propulsion”, IEEE Trans. Ind. Appl., Vol.33, No 4, pp.1062-1071 (2002)

(6) H. Naitoh, H. Ishikawa, A. Yamaba, and H. Katoh: "Current Control Design for Switched Reluctance Motors based on Their Electric Transfer Characteristic", Proc. 2004 Japan Industry Appli. Soc. Conference, Vol.1, pp.423-426 (2004) (in Japanese)

内藤治夫 · 石川裕記 · 山羽 聡 · 加藤大貴 : 「SRM の電気的伝達特 性に基づく電流制御系の設計法」, 平 16 電学産業応用部大講演論文 集 [1], pp.423-426 (2004)

( 7 ) H. Ishikawa, H. Katoh, and H. Naitoh: "Transfer Function Model for Linearized Torque Control for Switched Reluctance Motors", Proceedings of the International Power Electronics Conference Niigata, pp.1660-1664 (2005)

(8) R. Kurishnan: "Switched Reluctance Motor Drives", p.259, CRC Press (2001)

(9) T.J.E. Miller: "Electronic Control of Switched Reluctance Machines", p.38, Newness (2001)

１0）高橋安人：「システムと制御上」, p.43, 岩波書店 (1980)

（11）内藤治夫・多田隈進：「モデル規範適応制御による直流電動機の電機 子電流断続領域における制御法」,電学論, 106-B, 1, pp.31-38 (1986-1)

(12）松井信行・武田洋次：「見直されてきたリラクタンスモータ」, 電学 論 D, 118, 6, pp.685-690 (1998)

石 川 裕 記 (正員) 1970 年 7 月 15 日生。 1995 年 3 月岐阜

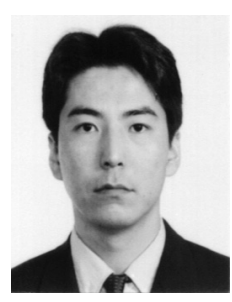
大学大学院工学研究科博士前期課程電子情報工学 専攻修了。同年 4 月岐阜大学助手。2007 年 4 月 岐阜大学助教。現在に至る。2006 年 6 月東京大 学より博士 (工学) の学位を授与される。主とし てスイッチトリラクタンスモータ, 太陽光発電シ ステム, ソフトスイッチング電力変換回路, 回路 シミュレータなどに関する研究に従事。IEEE，パ ワーエレクトロニクス学会会員。

小 牧 亮 子 (学生員) 2008 年 3 月岐阜大学大学院工学研究

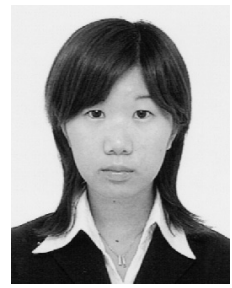
科博士前期課程人間情報システム工学専攻修了。 在学中は, 主としてスイッチトリラクタンスモー 夕の速度制御に関する研究に従事。

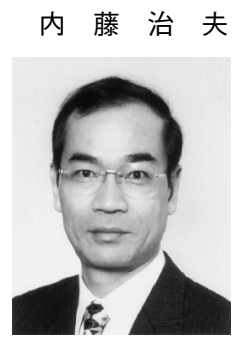

(正員) 1952 年 6 月 17 日生。1980 年 3 月東京 大学大学院工学系研究科電気工学専攻博士課程修 了, 工学博士。同年 4 月 (株) 東芝入社。(株) 東 芝より派遣され，1984 年 10 月 1985 年 6 月米国 カリフォルニア工科大学客員研究員, 1985 年 7 月 1986 年 4 月バージニア州立工科大学客員助教授。 2000 年 3 月（株）東芝退社。同年 4 月岐阜大学 教授, 現在に至る。パワーエレクトロニクスの研 究に従事。1983 年 5 月電気学会論文賞受賞。IEEE 会員。 
山 羽 聡 (非会員) 2005 年 3 月岐阜大学大学院工学研究科 博士前期課程電気電子工学専攻修了。在学中は, 主としてスイッチトリラクタンスモータの速度制

御に関する研究に従事。
加 藤 大 貴 (非会員) 2006 年 3 月岐阜大学大学院工学研究科

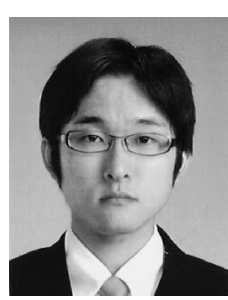
博士前期課程電気電子工学専攻修了。在学中は, 主としてスイッチトリラクタンスモータの速度制 御に関する研究に従事。 